\title{
Nitrogen effects on species' contributions to grazed pasture mixtures under nitrogen loss and application restrictions
}

\author{
Thinzar S. MYINT*, Alistair D. BLACK and Derrick J. MOOT \\ Field Research Centre, Department of Agricultural Sciences, \\ PO Box 85084, Lincoln University, Lincoln 7647, New Zealand \\ *Corresponding author: thinzar.myint@lincolnuni.ac.nz
}

\begin{abstract}
New regulations for the use of $\mathrm{N}$ fertiliser will impact on seed mixture decisions for new pastures. To help inform these decisions, effects of $\mathrm{N}$ on species and their interactions in pasture mixtures were examined. Ten mixtures of perennial ryegrass (PR), white clover (WC) and plantain (P) were sown on 31 March 2017 and grown $\pm \mathrm{N}$ fertiliser $(275 \mathrm{~kg} / \mathrm{ha}$ in Year 1 reduced to $200 \mathrm{~kg} \mathrm{~N} / \mathrm{ha} /$ year) under grazed and irrigated conditions. After 4 years, an equi-proportional mixture of PR and WC, based on seed count and equivalent to $12 \mathrm{~kg}$ PR and $7 \mathrm{~kg} \mathrm{WC}$ (coated seed)/ha, produced an optimal balance of increased total yield $(20.5 \mathrm{t}$ $\mathrm{DM} / \mathrm{ha} /$ year), weed suppression (4\% of total yield), metabolisable energy $(11 \mathrm{MJ} / \mathrm{kg} \mathrm{DM})$ and crude protein $(21 \%)$, regardless of $\mathrm{N}$ level. Pasture yield and quality responded to change in species proportions away from the optimal mixture, including the addition of $P$. The magnitude of the yield response was greater with rather than without $\mathrm{N}$ fertiliser, because the identity effects of PR and P, and the way all three species interacted, depended on $\mathrm{N}$ level. The optimal mixture without $\mathrm{N}$ fertiliser produced as much high-quality feed as mixtures with $\mathrm{N}$ fertiliser.
\end{abstract}

Keywords: diversity, environment, ryegrass, plantain, clover

\section{Introduction}

New regulations for the use of nitrogen $(\mathrm{N})$ fertiliser on grazed pastures (Ministry for the Environment 2021) will impact on seed mixture decisions for pasture renewal. Farmers may respond by growing more complex multi-species swards of different grasses, legumes and herbs to maintain soil, plant and animal components in their farm systems (Vibart et al., 2016). The challenge for pasture scientists will be to provide the scientific basis for seed mixture formulations to meet different farming needs as sustainably as possible. Which species to sow in different locations will depend on the growing conditions and purpose of the pasture (Stewart et al., 2014). However, decisions regarding the number and balance of species in the blend requires information about how a plant community interacts to utilise $\mathrm{N}$ and other natural resources.

One issue is the 'diversity effect', in which a species mixture can increase pasture production compared with the yield expected from individual species, which is called the 'identity effect'. Kirwan et al. (2009) explained how this diversity effect can result from interspecific interactions (e.g., niche partitioning and facilitation) among species. Niche partitioning (differences in resource use among species) can allow for more complete use of resources. For example, legumes can fix atmospheric $\mathrm{N}\left(\mathrm{N}_{2}\right)$ via symbiotic bacteria (rhizobia) in root nodules and utilise soil inorganic $\mathrm{N}$ - nitrate $\left(\mathrm{NO}_{3}^{-}\right)$and ammonium $\left(\mathrm{NH}_{4}^{+}\right)$, when available, whereas most non-legumes can only utilise soil inorganic N (Andrews et al., 2013; Burrows et al., 2021). Facilitation occurs when one species positively affects another by changing the environment, such as a legume that can increase soil inorganic $\mathrm{N}$ which improves the growth of a non-legume.

Kirwan et al. (2009) explained that interactions among species can be synergistic or antagonistic in their effect on pasture function, and a number of interactions may operate simultaneously. The diversity effect is the net result of all of these interactions. The strength of any interaction between two species may depend on the relative abundances of the species involved. Species may have the ability to interact, but, if they are not present in large enough abundance, this interaction will generally not be strong enough to detect. Species interactions may be complex and multispecies interactions may contribute to the diversity effect. Recent work has examined diversity effects in intensively managed grasslands in Europe (Connolly et al., 2009; Nyfeler et al., 2009; Finn et al., 2013; Kirwan et al., 2014; Connolly et al., 2018) and New Zealand (Ryan-Salter and Black 2012; Black et al., 2017, 2018; Black and Lucas 2018).

The amount of $\mathrm{N}$ fertiliser applied may affect species performance differently. It may affect the species identity effects, species interactions or both (Kirwan et al., 2009). For example, in mixtures of two grasses and two clovers managed by cutting, grass identity effects on annual yield increased, but clover identity effects and diversity effects did not change when $\mathrm{N}$ fertiliser 
was increased from 75 to $150 \mathrm{~kg} \mathrm{~N} / \mathrm{ha} /$ year in Ireland (Black et al., 2007) and from 50 to $450 \mathrm{~kg} \mathrm{~N} / \mathrm{ha} /$ year in Switzerland (Nyfeler et al., 2009). The influence of applied $\mathrm{N}$ on species interactions requires wider investigation to underpin generic decision support tools for grazed systems in NZ (Moot et al., 2021).

The objective of this study was to examine the interaction of $\mathrm{N}$ fertilisation with diversity effects (species identity, richness and relative abundance) in perennial ryegrass (Lolium perenne), white clover (Trifolium repens) and plantain (Plantago lanceolata) on the yield and quality of grazed and irrigated pasture. Results from the first year after sowing were previously published by Myint et al. (2019).

\section{Materials and Methods}

Ten mixtures of perennial ryegrass $c v$. Rely AR37 (PR), white clover $c v$. Quartz (WC) and plantain $c v$. Tonic (P) were grown $\pm \mathrm{N}$ fertiliser at Lincoln University, $\mathrm{NZ}$ (4338'57'S, $172^{\circ} 28^{\prime} 00^{\prime}$ 'E, $9 \mathrm{~m}$ a.s.1., $570 \mathrm{~mm}$ average annual rainfall and $11.7^{\circ} \mathrm{C}$ average air temperature). The soil was a Wakanui silt loam with medium fertility (pH 6, Olsen P 16 mg/l, Ca 7.3 mEq/100 g, Mg 0.98 $\mathrm{mEq} / 100 \mathrm{~g}, \mathrm{~K} 0.40 \mathrm{mEq} / 100 \mathrm{~g}, \mathrm{Na} 0.14 \mathrm{mEq} / 100 \mathrm{~g}$ and $\mathrm{SO}_{4}-\mathrm{S} 4 \mu \mathrm{g} / \mathrm{g}$ in the top $7.5 \mathrm{~cm}$ on 20 March 2017) and has good available water capacity $(140-150 \mathrm{~mm}$ in the top $0.5 \mathrm{~m}$ ). The site was a PR/WC pasture for 2 years, then in annual clover for 6 months and fallow during summer.

The species represented three functional groups: grass (PR), legume (WC) and herb (P). The seed mixtures varied in species proportions, based on a simplex design (Cornell 2002). There were three single-species mixtures (monocultures), three binary mixtures $(50 \%$ of each of two species), one even mixture $(33.3 \%$ of each species) and three mixtures dominated in turn by each species (66.6\% of one species and $16.6 \%$ of each of the other species). The mixtures were repeated at two seed densities (1000 and 2000 seeds $\left./ \mathrm{m}^{2}\right)$ to avoid issues arising from replacement series design (Kirwan et al., 2009). The $\pm \mathrm{N}$ fertiliser levels were determined by local practice. The $+\mathrm{N}$ level was reduced from $275 \mathrm{~kg} \mathrm{~N} / \mathrm{ha}$ in Year 1 (2017/2018) to $200 \mathrm{~kg} \mathrm{~N} / \mathrm{ha} /$ year in anticipation of restrictions in the application of synthetic $\mathrm{N}$ fertiliser (Ministry for the Environment 2021).

Plot size was $2.1 \mathrm{~m} \times 6 \mathrm{~m}$. Ten plots arranged side by side in 12 rows (each $21 \mathrm{~m} \times 6 \mathrm{~m}$ ), with $2 \mathrm{~m}$-wide headlands between and around rows, which fitted the experiment within the available area. Mixtures were randomly assigned to plots within rows, seed densities to adjacent rows and $\mathrm{N}$ levels to adjacent pairs of rows, giving three replicate blocks and 120 plots in total.

The seed was obtained from PGG Wrightson Seeds, Christchurch, NZ. PR was certified to be infected with fungal endophyte (Epichloë festucae var. lolii) strain AR37. PR and P were coated with insecticide and fungicide (Superstrike ${ }^{\circledR}$ ) and WC was coated with lime, molybdenum, insecticide and rhizobia (Rhizobium leguminosarum bv. trifolii) (Superstrike Clover $\left.{ }^{\circledR}\right)$. Thousand seed weight was 2.4, 1.4 and 1.9 $\mathrm{g}$ and germination (incubated at $20^{\circ} \mathrm{C}$ for 14 days) was 98, 93 and $95 \%$ for PR, WC and P, respectively.

The site was sprayed out on 16 March 2017 (glyphosate, $470 \mathrm{~g} / 1$ at $2 \mathrm{l} / \mathrm{ha}$ with $200 \mathrm{l} / \mathrm{ha}$ water; WeedMaster TS470, Nufarm, NZ), cultivated on 22 March 2017 (rota crumbler), fertilised on 23 March 2017 (9\% P, 11\% S, 20\% Ca at $300 \mathrm{~kg} / \mathrm{ha}$; Superphosphate, Ravensdown, NZ), cultivated into a seed bed on 29 March 2017 (heavy grubber then power harrow and Cambridge roller) and sown on 31 March 2017 (plot seeder with 14 coulters spaced $150 \mathrm{~mm}$ apart to $10-15$ mm depth; Flexiseeder, Christchurch, NZ). Headlands were sown with PR $c v$. Rely AR37.

The plots were grazed by sheep eight times annually, except for the first harvest on 4-6 August 2017 when the plots were mown to 3-4 cm (LawnMaster $725 \mathrm{EXI}$; Steelfort, NZ) to minimise damage to the new swards. The sheep were removed once the plots had been defoliated to approximately 3-6 cm height and then all plots were mown to 3-4 cm (Model C19; Walker, NZ), usually after 3-5 days. The $\mathrm{N}$ fertiliser $(46 \% \mathrm{~N}$; Urea, Ravensdown, NZ) was applied at $50 \mathrm{~kg} \mathrm{~N} / \mathrm{ha}$ after sowing (1 April 2017), $50 \mathrm{~kg} \mathrm{~N} / \mathrm{ha}$ after the first harvest and then $25 \mathrm{~kg} \mathrm{~N} / \mathrm{ha}$ after each grazing.

Irrigation was applied at 3-5-week intervals, between October and April each year, based on a soil water balance. Annual (1 July to 30 June) rainfall was 745 , 514,475 and $519 \mathrm{~mm}$ (obtained from Broadfields, about $2 \mathrm{~km}$ north of the site), irrigation was 220,217, 435 and $540 \mathrm{~mm}$ and maximum soil moisture deficit was 125 , 117, 127 and $116 \mathrm{~mm}$ for Years 1 to 4, respectively.

Insecticide (metaldehyde, $50 \mathrm{~g} / \mathrm{kg}$ at $8 \mathrm{~kg} / \mathrm{ha}$; Metare ${ }^{\circledR}$, De Sangosse, NZ) was applied on 16 May 2017 to control slugs (Deroceras reticulatum). Herbicide (aminopyralid, $30 \mathrm{~g} / \mathrm{l}$ at 2 1/ha with 200 1/ha water; T-Max ${ }^{\circledR}$, Dow AgroSciences, NZ) was sprayed on PR and $\mathrm{P}$ monoculture plots to suppress voluntary WC on 15 February 2019. Herbicide (thifensulphuronmethyl, $500 \mathrm{~g} / \mathrm{kg}$ at $1.5 \mathrm{~g} / 101$ water; Harmony ${ }^{\circledR}$ 50SG, DuPont, NZ) was spot-sprayed on dock (Rumex obtusifolius) plants in many plots on 13 March 2019. Grass grub (Costelytra giveni) damaged a small area of some plots in autumn 2021, which did not warrant insecticide and affected areas were avoided at sampling.

Measurements of pasture mass and composition were taken at each defoliation. Before the first harvest, a 0.2 $\mathrm{m}^{2}$ quadrat in each plot was cut to $1 \mathrm{~cm}$ height (Cordless Sheep Clippers 12V 180W; Trade Tested, NZ) for dry matter (DM) and botanical analyses. Before each grazing in Years $1-3$, a $0.33 \mathrm{~m} \times 6 \mathrm{~m}$ strip was mown 
through each plot to 3-4 cm height (LawnMaster 725 EXI; Steelfort, NZ). The mown herbage was weighed and a subsample taken for DM analysis. The remainder was left on the headlands for the sheep to eat. A sample was then cut to 3-4 cm (sheep clippers) from several randomly spread positions in the plot for botanical analysis. However, before grazing on 2-6 April 2020 and at each grazing in Year 4, the quadrat method was used.

Because the quadrats were cut to $1 \mathrm{~cm}$ height and the plots were defoliated to $3-4 \mathrm{~cm}$, after defoliation a 0.2 $\mathrm{m}^{2}$ quadrat in each high-density monoculture and even mixture was cut to $1 \mathrm{~cm}$ to determine residual mass. The residual mass of the mixture was calculated as the sum of monoculture masses in the same block and $\mathrm{N}$ level weighted by the sown species' proportions. The observed and predicted values of the even mixture were used to check agreement.

The samples were stored at $3-4^{\circ} \mathrm{C}$. Within $1-2$ hours, at least $100 \mathrm{~g}$ of the mown sample was dried at $65^{\circ} \mathrm{C}$ to constant weight (2-3 days) in a force-draft oven. Within 3-5 days, the clipped sample was mixed thoroughly, divided into quarters, diagonally opposite quarters were discarded, and the remaining quarters were mixed and quartered again until the sample to be sorted was down to about 400 pieces. The pieces were sorted into five fractions: each sown species, voluntary WC (VWC) and weed. Voluntary plants could not be separated from sown plants of the same species. For each plot not sown with PR or P, volunteer plants of those two species were included as weeds. Once sorted, each fraction was dried at $65^{\circ} \mathrm{C}$. The fresh weight and DM proportion of the mown sample were used to calculate total yield (TY). This was then applied to the dry weights of the separated fractions to calculate component yields, including weed yield (WY), which was the sum of VWC and weed.

The quadrat sample was analysed much like the clipped sample, except that all the composite material was dried, and the dry weights of the composite sample and separated fractions were used to calculate total pasture mass, and pre-grazing pasture mass less the previous residual pasture mass equalled total yield.

The dried composite samples from the high-density plots in Years 2-4 were milled (Ultra Centrifugal Mill ZM 200; Retsch, Germany) and analysed for nutritive value (NIRSystems II 5000; Foss, USA) at the Analytical Laboratory, Department of Agricultural Science, Lincoln University. The scan predicted several feed quality parameters, including metabolisable energy (ME) and crude protein (CP).

Interactions of $\mathrm{N}$ with species identity and species interaction effects on pasture yield and quality were quantified using diversity-interaction modelling (Kirwan et al., 2009). This is a regression-based approach that relates a pasture function, e.g., yield, to species identity and interaction effects. Equation 1 was fitted to each response $y$ (TY, WY, ME and $\mathrm{CP}$ ) average across grazing events and at each grazing:

$$
\begin{aligned}
& \mathrm{y}=\sum_{i=1}^{s} \beta_{i} x_{i}+\alpha A+\sum_{\substack{i, j=1 \\
i<j}}^{s} \delta_{i j} x_{i} x_{j}+\delta_{i j k} x_{i} x_{j} x_{k} \\
& +\sum_{i=1}^{s} \gamma_{i} x_{i} \times \mathrm{N}+\sum_{\substack{i, j=1 \\
i<j}}^{s} \gamma_{i j} x_{i} x_{j} \times \mathrm{N}+\gamma_{i j k} x_{i} x_{j} x_{k} \times \mathrm{N}+\varepsilon .
\end{aligned}
$$

In the model, $x$ was the initial proportion of the $i$ th species in a mixture formed with species drawn from a pool of $s$ species $(x=0$ if the species is not in the mixture). The coefficient $\beta_{i}$ was the estimated contribution of species $i$ in a mixture (its identity effect) and, if $x=1, \beta_{i}$ estimated the performance of a monoculture. $\alpha$ reflected the effect of changing seed density $(A)$ on a pasture function ( $A$ is centred to average zero so that all other terms in the model are interpreted at average seed density). The $\delta_{i j}$ term measured the strength of interspecific interaction between species $i$ and $j$, and $\delta_{i j k}$ tested for a three-way interaction between all three species. The coefficients $\gamma_{i}, \gamma_{i j}$ and $\gamma_{i j k}$ measured the impact of $\mathrm{N}$ (coded 1 for $+\mathrm{N}$ and -1 for $-\mathrm{N}$ ) on the identity effect of species $i$, the interaction between species $i$ and $j$, and the three-way interaction, respectively. $\varepsilon$ was a random error term.

The model was fitted using the mixture regression method in Minitab ${ }^{\circledR} 19$ statistical software. The response optimization procedure was used to identify the optimal seed mixture that maximised average TY, $\mathrm{ME}$ and $\mathrm{CP}$, and minimised WY simultaneously. All four functions were considered equally desirable in the optimisation analysis.

\section{Results}

The contour plots (Figure 1) show how changes in species proportions and $\mathrm{N}$ levels affected pasture yield and quality averaged over grazing events. The greatest TY with low WY, high ME and CP resulted from an equi-proportional mixture of $\mathrm{PR}$ and $\mathrm{WC}$, regardless of $\mathrm{N}$ level. The average TY from the optimal mixture was the same at both $\mathrm{N}$ levels (average $2.57 \mathrm{t} \mathrm{DM} / \mathrm{ha}(20.5$ t DM/ha/year) with $0.09 \mathrm{t}$ weeds (4\% TY), $11 \mathrm{MJ} / \mathrm{kg}$ $\mathrm{DM}$ of $\mathrm{ME}$ and $21 \% \mathrm{CP}$ ). The addition of $\mathrm{P}$ decreased WY further - a move from the centre of the PR-WC edge to the area of no WY in the interior of the response surface. However, that change was at the expense of TY without $\mathrm{N}$ fertiliser and $\mathrm{ME}$ and $\mathrm{CP}$ at both $\mathrm{N}$ levels.

The three corners of the surface (Figure 1) depict the species identity effects in monocultures. A linear surface between the three corners indicates the contribution of the species identity effects in mixtures. The identity 


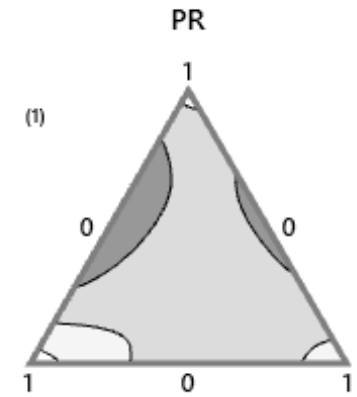

WC

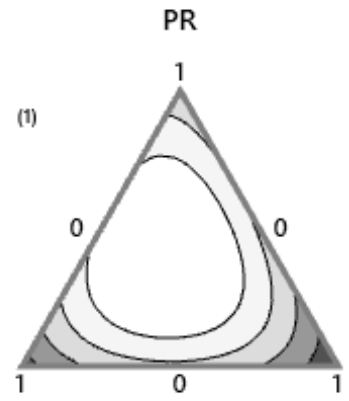

WC

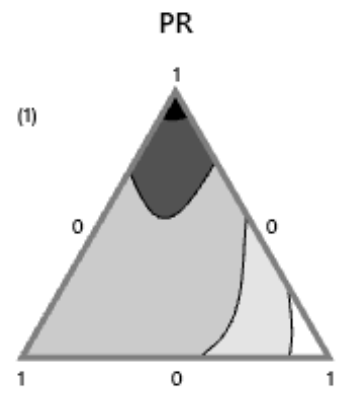

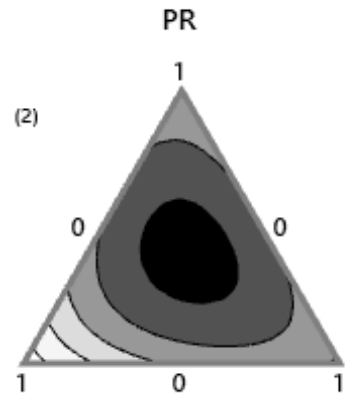

P WC

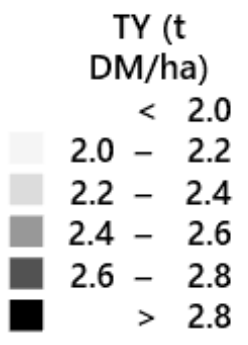

PR

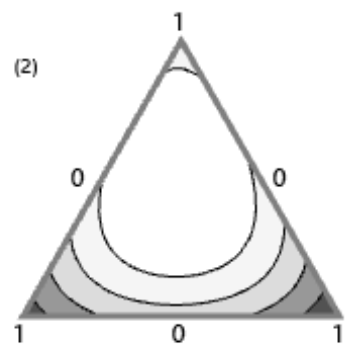

WC

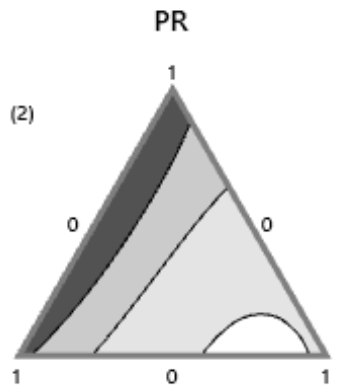

$\mathrm{ME}(\mathrm{MJ} / \mathrm{kg}$

DM)

$<10.7$

$10.7-10.8$

$10.8-10.9$

$10.9-11.0$

$>11.0$

WC

P WC
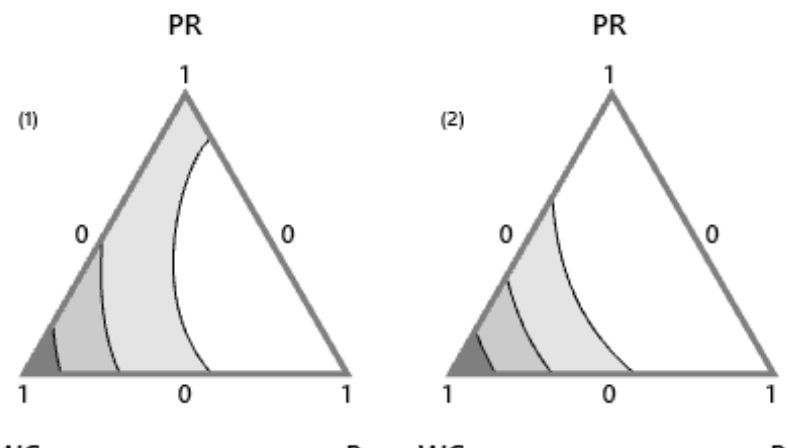

WC

P WC

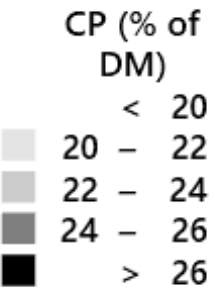

Figure 1 Contour plots of pre-grazing total yield (TY), weed yield (WY), metabolisable energy (ME) and crude protein (CP) -N (1) and $+\mathrm{N}(2)$ fertiliser averaged across 32 grazing events over 4 years, predicted from Equation 1 as functions of sown proportions of perennial ryegrass (PR), white clover (WC) and plantain (P). 


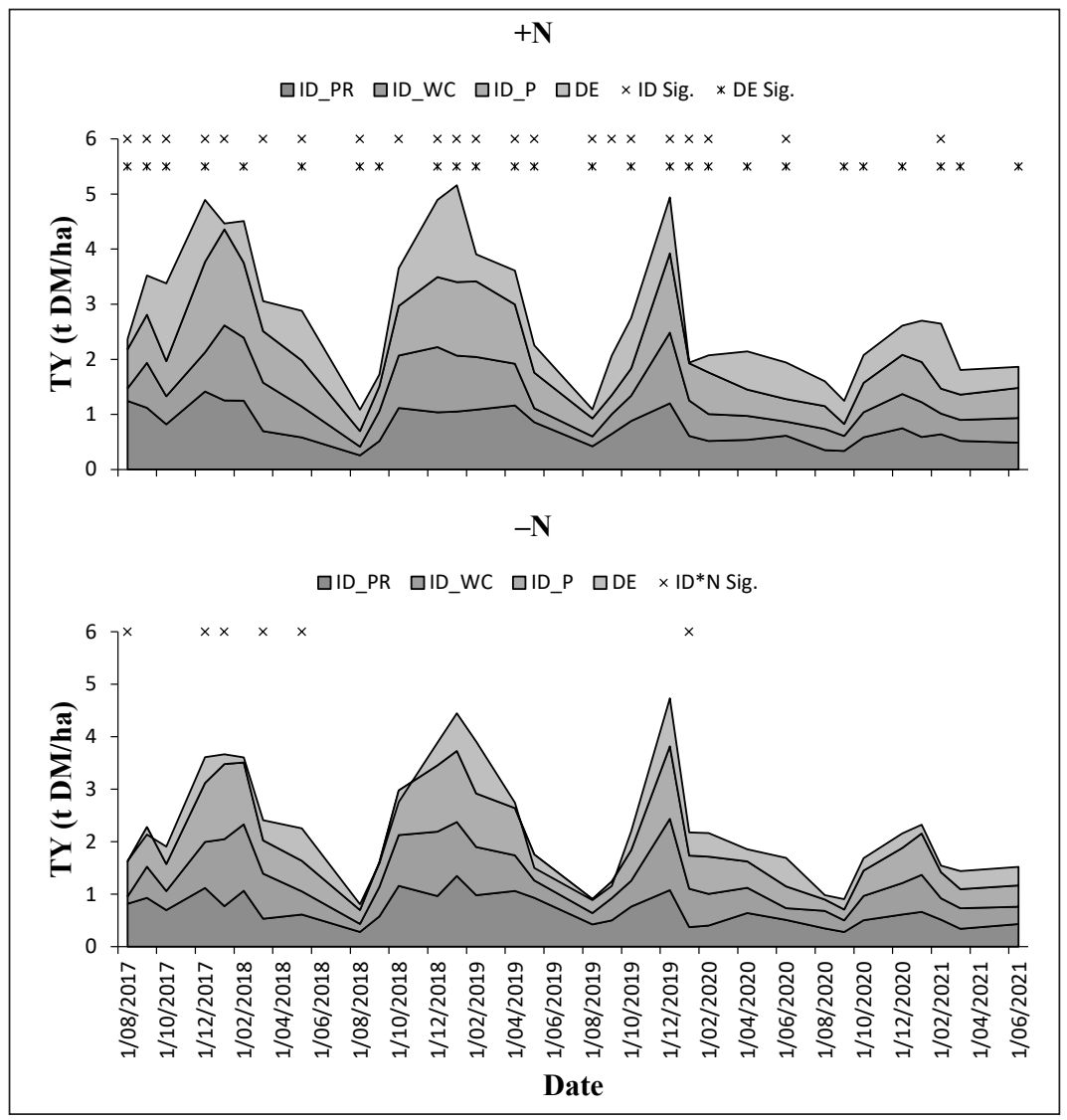

Figure 2

Contributions of species identity effects (ID) and overall diversity effect (DE; the combination of individual interspecific interactions) to pre-grazing total yield (TY) predicted from Equation 1 for an even mixture of perennial ryegrass (PR), white clover (WC) and plantain (P) $\pm \mathrm{N}$ fertiliser across 32 grazing events over 4 years. Indicated identity effects (ID Sig.), diversity effects (DE Sig.) and influence of $\mathrm{N}$ on ID (ID*N Sig.) are significant at the $5 \%$ level. effects differed $(\mathrm{P}<0.001)$ among species, whereby monocultures of PR and P had greater TY than WC, PR had lower WY than WC, P, PR and WC had higher ME than $\mathrm{P}$, and $\mathrm{WC}$ had higher $\mathrm{CP}$ than PR and P. However, monocultures of PR and P had less TY and PR had more WY without than with $\mathrm{N}$ fertiliser $(\mathrm{P}<0.05)$. The average identity effect of the optimal mixture was 2.10 $\mathrm{t} \mathrm{DM} /$ ha $(16.8 \mathrm{t} \mathrm{DM} / \mathrm{ha} /$ year $)$ with $0.31 \mathrm{t}$ weeds $(15 \%$ of TY), $10.9 \mathrm{MJ} / \mathrm{kg} \mathrm{DM} \mathrm{ME}$ and $23 \% \mathrm{CP}$ at the $+\mathrm{N}$ level, compared with $1.96 \mathrm{t} \mathrm{DM} /$ ha with $0.36 \mathrm{t}$ weeds $(18 \%$ of $\mathrm{TY}), 10.9 \mathrm{MJ} / \mathrm{kg} \mathrm{DM} \mathrm{ME}$ and $23 \% \mathrm{CP}$ at the $-\mathrm{N}$ level.

The positive or negative curvature on the surface of Figure 1 depicts diversity effects $(\mathrm{P}<0.001)$ derived from synergistic or antagonistic interspecific interactions among species in mixtures. The subtle curvature response for ME was not significant. The interaction of PR with WC on TY was stronger than PR with P or WC with $\mathrm{P}$, which was indicated by the higher surface on the PR-WC edge. Interactions were stronger for PRWC and WCP than PRP on WY, and similar for PRWC and $\mathrm{WCP}$ on $\mathrm{CP}$. The extra curvature on the surface interior of WY depicts a three-way interaction $(\mathrm{P}<0.01)$, where a third species influenced the interaction between two species. $\mathrm{N}$ level did not alter any interaction effects.
However, a negative three-way interaction $(\mathrm{P}<0.01)$ for $\mathrm{TY}$ occurred without $\mathrm{N}$ fertiliser. The average diversity effects of the optimal mixture were $0.48 \mathrm{t} \mathrm{DM} /$ ha more TY (3.85 t DM/ha/year), $0.20 \mathrm{t} \mathrm{DM/ha} \mathrm{less} \mathrm{WY} \mathrm{and}$ $1.6 \%$ less CP for the $+\mathrm{N}$ level compared with $0.60 \mathrm{t}$ $\mathrm{DM} /$ ha more TY (4.76 t DM/ha/year), $0.28 \mathrm{t} \mathrm{DM} / \mathrm{ha}$ less $\mathrm{WY}$ and $1.1 \%$ less $\mathrm{CP}$ for the $-\mathrm{N}$ level.

The species interaction effects resulted in a better fit of the predictive model (Equation 1) to average TY $\left(\mathrm{R}^{2}\right.$ $=64 \%$ and adjusted $\left.\mathrm{R}^{2}=58 \%\right)$, $\mathrm{WY}(77 \%$ and $73 \%)$ and $\mathrm{CP}(78 \%$ and $75 \%)$ than $\mathrm{ME}(40 \%$ and $31 \%)$. Therefore, the effects of species on TY, WY and CP were derived from synergistic or antagonistic species interactions and from a linear combination of species identity effects in mixtures, while the effects of species on ME were only derived from identity effects. There were no effects of seed density on average pre-grazing TY and WY.

The effects of species and $\mathrm{N}$ levels on pasture yield and quality changed over grazing events. For example, there were marked changes in species identity and overall diversity effects (the aggregate of individual interspecific interactions) on predicted TY of an even mixture of three species (Figure 2). At average seed 


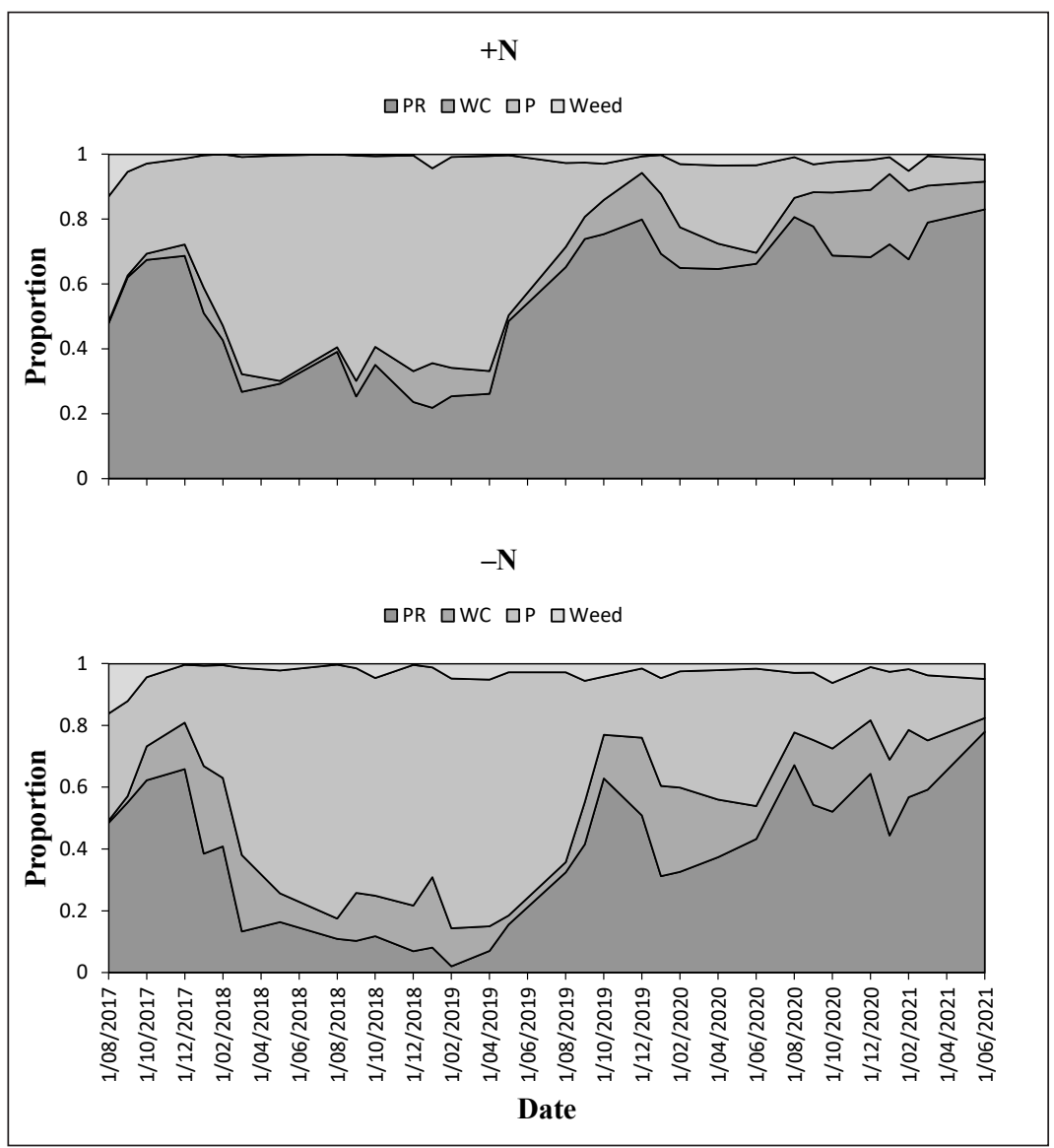

\section{Figure 3}

Relative abundance of perennial ryegrass $(P R)$, white clover (WC), plantain (P) and weed of an even mixture of $\mathrm{PR}, \mathrm{WC}$ and $\mathrm{P} \pm \mathrm{N}$ fertiliser across 32 grazing events over 4 years. density and $\mathrm{N}$ level, the identity effect in this mixture differed $(\mathrm{P}<0.05)$ among species at 21 of 24 grazing events over Years 1-3, but only at one event in Year 4. The three species interacted to produce positive diversity effects $(\mathrm{P}<0.05)$ for 26 of all 32 grazing events. $\mathrm{N}$ level only altered $(\mathrm{P}<0.05)$ species identity effects for six grazing events, mostly in Year 1, and did not alter the overall diversity effect across all events.

The relative abundances of species, including weeds, changed substantially over time. For the even mixture of three species at average density $(33.3 \%$ of each species at sowing), PR and $\mathrm{P}$ were dominant at the start of Year 1 at the expense of WC and weeds (Figure 3 ). PR then reduced in summer, while P increased to dominate the mixture until autumn in Year 2, when PR started to recover and became the most abundant species in Years 3 and 4. WC seldom exceeded $20 \%$ and weeds were $15 \%$ or less. PR decreased and WC and P increased with the decrease in $\mathrm{N}$ level.

\section{Discussion}

After 4 years, the equi-proportional mixture of PR and WC (based on seed count) produced the most desirable balance of increased pasture yield, weed suppression, $\mathrm{ME}$ and $\mathrm{CP}$ regardless of $\mathrm{N}$ level (Figure 1). Pasture yield and quality responded to change in species proportions away from the optimal mixture, including the addition of P. However, the magnitude of the responses of TY and WY was more pronounced at the $+\mathrm{N}$ level, where fertiliser application was restricted in anticipation of the new regulations (Ministry for the Environment 2021), than at the $-\mathrm{N}$ level (with no $\mathrm{N}$ fertiliser applied). The different responses occurred because the identity effects of PR and P, and the way all three species interacted to produce diversity effects, depended on $\mathrm{N}$ level.

The species identity effects (Figure 1) could be related to the amount of natural resources (e.g., light, water and nutrients) the plants used and how these were allocated to different organs (Hay and Porter 2006). The three species appeared to differ in resource use. The superior yield and weed control of PR suggested an increased use of resources, which reduced availability to weeds (Connolly et al., 2018). The greater CP content of WC than PR and P reflected its ability to fix $\mathrm{N}_{2}$ and utilise soil $\mathrm{NO}_{3}{ }^{-}$and $\mathrm{NH}_{4}{ }^{+}$(Andrews et al., 2013). The 
similar WC identity effects across $\mathrm{N}$ levels suggested that WC continued to derive a proportion of its total $\mathrm{N}$ from fixation under the $+\mathrm{N}$ conditions (Peoples et al., 2012). The decreased yield of $P R$ and $P$ and decreased weed control in PR due to the removal of $\mathrm{N}$ fertiliser from the system were both logical (both species can only utilise soil $\mathrm{NO}_{3}{ }^{-}$and $\mathrm{NH}_{4}^{+}$) and in line with farmer experience.

The diversity effects (Figure 1) were thought to be the result of niche partitioning and facilitation among species (Kirwan et al., 2009). The simple mixtures of two or three species appeared to use resources more completely than monocultures, and further reduced the availability of resources to weeds (Connolly et al., 2018). WC appeared to facilitate the growth of PR and $\mathrm{P}$ by increasing soil inorganic $\mathrm{N}$ at both fertiliser levels, which increased the amount of light the plants captured and allocated to organs (Hay and Porter 2006). However, the interaction of PR with P suggested that this and the other diversity effects may have resulted from shifts towards $\mathrm{PR}$ and $\mathrm{P}$ dominance over time (Figure 3). The reduction in CP from combining WC with PR and $\mathrm{P}$ may indicate a dilution of herbage $\mathrm{N}$ with increased yield (Lemaire et al., 2007).

The interactions involving all three species (Figure 1) implied that a third species influenced the interaction of the other two species. Such complex interactions are less common than interactions between pairs of legume and non-legume species (Black et al., 2017). Diversityinteraction models that include only identity effects and separate pairwise interaction terms can explain most of the variation in the response (Connolly et al., 2009). In this study, the decrease in $\mathrm{N}$ level appeared to have a negative impact on the overall diversity effect on TY of mixtures with three species (Figure 2). For example, in a mixture of three species equally represented, the sum of pairwise interactions was similar at $+\mathrm{N}$ and $-\mathrm{N}$ levels ( 0.46 and $0.56 \mathrm{t} \mathrm{DM} / \mathrm{ha})$. However, the three-way interaction was not significant at the $+\mathrm{N}$ level $(0.19 \mathrm{t}$ $\mathrm{DM} / \mathrm{ha})$ and negative at the $-\mathrm{N}$ level $(-0.30 \mathrm{t} \mathrm{DM} / \mathrm{ha})$, giving a greater overall diversity effect at $+\mathrm{N}$ than $-\mathrm{N}$ (0.65 vs. $0.26 \mathrm{t} \mathrm{DM} / \mathrm{ha}$, or 5.24 vs. $2.11 \mathrm{t} \mathrm{DM} /$ ha/year). This explained the decrease in the response surface when a third species was added to the seed mixture with no $\mathrm{N}$ fertiliser in the system.

The optimal seed mixture (equal proportions of PR and WC based on seed count; Figure 1) was equivalent to sowing rates of $12 \mathrm{~kg}$ PR and $7 \mathrm{~kg} \mathrm{WC}(19 \mathrm{~kg}$ total seed)/ha at the low seed density $\left(1000 \mathrm{seeds} / \mathrm{m}^{2}\right)$ and double at the high seed density $\left(2000 \mathrm{seeds} / \mathrm{m}^{2}\right)$. The optimal seed mixture at low seed density had less PR and more WC than most commercial mixtures in NZ. A typical seed blend may contain about $20 \mathrm{~kg}$ PR and 4 $\mathrm{kg}$ coated WC/ha (Stewart et al., 2014). The consistent species identity and interaction effects across the two overall seed densities in Year 1 (Myint et al., 2019), and the lack of effect of seed density across Years 1-4, suggested that each species responded to the sown populations through size-density compensation of their tillers, stolons or crown shoots (Brougham 1954; Matthew et al., 1996). This meant that the optimal species' proportions were robust across overall sowing rates within the range of industry recommendations in NZ. The lack of any effects of seed density means that the optimal seed mixture could be sown at 1000 seeds/ $\mathrm{m}^{2}$.

In Myint et al. (2019), the initial estimation of the optimal seed blend after 1 year of annual TY data included less PR and WC and more P (34\% PR, 26\% WC and $40 \% \mathrm{P}$ ) than the optimum estimated after 4 years of yield and quality data. The absence of $\mathrm{P}$ in the revised optimum suggested that it had less and PR and WC had more influence on mixture yield and quality over the next 3 years. This result reflected the different establishment and persistence traits among the three species, whereby PR and $\mathrm{P}$ are both fast to establish but $\mathrm{PR}$ is temporally more persistent, and $\mathrm{WC}$ is slow to establish and temporally persistent (Stewart et al., 2014).

The seasonal changes in TY of the even mixture of three species were associated with changes in species identity and diversity effects (Figure 2). The different identity effects among species over the first 2.5 years, and similar identity effects thereafter, were consistent with the seasonal growth and persistence traits expected from each species (Stewart et al., 2014). N level altered the identity effects in Year 1 when the $+\mathrm{N}$ level was 275 $\mathrm{kg} \mathrm{N} / \mathrm{ha}$, but not in Years 2-4 when the $+\mathrm{N}$ level was restricted to $200 \mathrm{~kg} \mathrm{~N} / \mathrm{ha} /$ year. The overall diversity effect persisted across $\mathrm{N}$ levels and over 4 years, but appeared to be stronger in the main growing season than winter, possibly due to greater $\mathrm{N}_{2}$ fixation by WC (Andrews et al., 2011). Therefore, species identity and interaction effects did not change with decreased $\mathrm{N}$ fertiliser application from $200 \mathrm{~kg} \mathrm{~N} / \mathrm{ha} /$ year to none in Years 2-4.

The species identity and diversity effects occurred alongside substantial shifts in species' relative abundances, including weeds, over the 4 years (Figure $3)$. The species' dynamics in the mixtures were most likely associated with differences in relative growth rates among the species (Brophy et al., 2017). In Myint et al. (2019), analysis of yield in Year 1 as a function of species composition in the sward captured the dominant effects of PR and P over that period. Further analysis is necessary to capture the effects of these shifts in relative abundances over years in the diversityinteraction model. In this study and others (Finn et al., 2013; Black et al., 2017, 2018; Black and Lucas 2018), mixtures of two to four legume and non-legume species 
increased pasture yield compared with that expected from the individual species. Any further increase in the number of sown grass, clover and herb species may change the botanical composition, but not the yield and quality of the pasture.

\section{Conclusions}

After 4 years, an equi-proportional seed mixture of PR and WC (based on seed count) produced an optimal balance of increased pasture yield, weed suppression, $\mathrm{ME}$ and $\mathrm{CP}$ under two restricted levels of $\mathrm{N}$ fertiliser application. Pasture yield and quality responded to changes in species proportions away from the optimal mixture, including the addition of $\mathrm{P}$. The effects of plant diversity and $\mathrm{N}$ level were explained in relation to species identity and interaction effects. The optimal mixture without $\mathrm{N}$ fertiliser produced as much higher quality feed with $\mathrm{N}$ fertiliser, but without the associated greenhouse gas emissions from $\mathrm{N}$ fertiliser production and use.

\section{ACKNOWLEDGEMENTS}

Funding for this project was provided by Beef + Lamb New Zealand, Ministry of Business, Innovation and Employment, Seed Force New Zealand and PGG Wrightson Seeds under the 'Hill Country Futures' research programme (BLNZT1701). Funding for Thinzar Soe Myint was provided by NZ Aid Scholarship. Technical support was provided by Dave Jack, Dan Dash, Keith Pollock, Malcolm Smith, Jason Nolan and Breanna Taylor.

\section{REFERENCES}

Andrews M, James EK, Sprent JI, Boddey RM, Gross E, dos Reis Jr FB. 2011. Nitrogen fixation in legumes and actinorhizal plants in natural ecosystems: values obtained using ${ }^{15} \mathrm{~N}$ natural abundance. Plant Ecology \& Diversity 4: 131-140. https://doi.org/10.1080/175 50874.2011.644343

Andrews M, Raven JA, Lea PJ. 2013. Do plants need nitrate? The mechanisms by which nitrogen form affects plants. Annals of Applied Biology 163: 174199. https://doi.org/10.1111/aab.12045

Black AD, Anderson S, Dalgety SK. 2017. Identification of pasture mixtures that maximise dry matter yield. Journal of New Zealand Grasslands 79: 103-109. https://doi.org/10.33584/jnzg.2017.79.563

Black AD, Anderson S, Dalgety SK, Hassall CA, Myint TS, Vreugdenhil SR. 2018. Yield benefits of pasture mixtures with species drilled in the same and alternate rows. Journal of New Zealand Grasslands 80: 243 244. https://doi.org/10.33584/jnzg.2018.80.327

Black AD, Kirwan L, Finn J. 2007. Plant species diversity benefits in grass/legume swards were consistent across three sites in Ireland. Proceedings of the Agricultural Research Forum, 12 March 2007, Tullamore, Ireland. Pg. 66.

Black AD, Lucas RJ. 2018. Dry matter yield of dryland and irrigated mixtures of Caucasian clover, white clover and perennial ryegrass over 5 years at Lincoln University. Journal of New Zealand Grasslands 80: 73-80. https://doi.org/10.33584/jnzg.2018.80.336

Brophy C, Finn JA, Lüscher A, Suter M, Kirwan L, Sebastià MT, Helgadóttir Á, Baadshaug $\mathrm{OH}$, Bélanger G, Black A, Collins RP, Čop J, Dalmannsdóttir S, Delgado I, Elgersma A, Fothergill M, FrankowLindberg BE, Ghesquiere A, Golinska B, Golinski P, Grieu P, Gustavsson AM, Höglind M, HugueninElie O, Jørgensen M, Kadziuliene Z, Kurki P, Llurba R, Lunnan T, Porqueddu C, Thumm U, Connolly J. 2017. Major shifts in species' relative abundance in grassland mixtures alongside positive effects of species diversity in yield: a continental-scale experiment. Journal of Ecology (Oxford) 105: 12101222. https://doi.org/10.1111/1365-2745.12754

Brougham, RW. 1954. Pasture establishment studies I. The effect of grass seeding rate on the establishment and development of pastures of short rotation ryegrass, red and white clovers. New Zealand Journal of Science and Technology A35: 518-538.

Burrows E, Mills A, Dash D, Jack D, Andrews M, Black AD. 2021. Nitrogen effects on $\mathrm{N}_{2}$ fixation, growth and feed quality of lucerne and perennial lupin. Journal of New Zealand Grasslands 83: 79-82.

Connolly J, Finn JA, Black AD, Kirwan L, Brophy C, Lüscher A. 2009. Effects of multi-species swards on dry matter production and the incidence of unsown species at three Irish sites. Irish Journal of Agricultural and Food Research 48: 243-260. http:// hdl.handle.net/11019/429

Connolly J, Sebastià MT, Kirwan L, Finn JA, Llurba R, Suter M, Collins RP, Porqueddu C, Helgadóttir Á, Baadshaug OH, Bélanger G, Black A, Brophy C, Čop J, Dalmannsdóttir S, Delgado I, Elgersma A, Fothergill M, Frankow-Lindberg BE, Ghesquiere A, Golinski P, Grieu P, Gustavsson AM, Höglind $\mathrm{M}$, Huguenin-Elie $\mathrm{O}$, Jørgensen $\mathrm{M}$, Kadziuliene Z, Lunnan T, Nykanen-Kurki P, Ribas A, Taube F, Thumm U, Vliegher AD, Lüscher A. 2018. Weed suppression greatly increased by plant diversity in intensively managed grasslands: A continental-scale experiment. Journal of Applied Ecology 55: 852862. https://doi.org/10.1111/1365-2664.12991

Cornell JA. 2002. Experiments with Mixtures: Designs, Models, and the Analysis of Mixture Data. 3rd ed. Chichester: Wiley, 305 p. https://doi. org/10.1002/9781118204221

Finn JA, Kirwan L, Connolly J, Sebastià MT, Helgadóttir Á, Baadshaug OH, Bélanger G, Black A, Brophy C, Collins RP, Čop J, Dalmannsdóttir 
S, Delgado I, Elgersma A, Fothergill M, FrankowLindberg BE, Ghesquiere A, Golinska B, Golinski P, Grieu P, Gustavsson AM, Höglind M, HugueninElie O, Jørgensen M, Kadziuliene Z, Kurki P, Llurba R, Lunnan T, Porqueddu C, Suter M, Thumm U, Lüscher A. 2013. Ecosystem function enhanced by combining four functional types of plant species in intensively managed grassland mixtures: a 3-year continental-scale field experiment. Journal of Applied Ecology 50: 365-375. https://doi.org/10.1111/13652664.12041

Hay RJM, Porter JR. 2006. The Physiology of Crop Yield. Oxford: Blackwell Publishing Ltd, 1-275 p. https://ebookcentral.proquest.com/

Kirwan L, Connolly J, Brophy C, Baadshaug O, Bélanger G, Black A, Carnus T, Collins R, Čop J, Delgado I, De Vliegher A, Elgersma A, FrankowLindberg B, Golinski P, Grieu P, Gustavsson AM, Helgadóttir Á, Höglind $M$, Huguenin-Elie $O$, Jørgensen M, Kadziuliene Z, Lunnan T, Lüscher A, Kurki P, Porqueddu C, Sebastià MT, Thumm U, Walmsley D, Finn J. 2014. The Agrodiversity Experiment: three years of data from a multisite study in intensively managed grasslands. Ecology 95: 2680. https://doi.org/10.1890/14-0170.1

Kirwan L, Connolly J, Finn JA, Brophy C, Lüscher A, Nyfeler D, Sebastià MT. 2009. Diversity-interaction modeling: estimating contributions of species identities and interactions to ecosystem function. Ecology 90: 2032-2038. https://doi.org/10.1890/081684.1

Lemaire G, van Oosterom E, Sheehy JE, Jeuffroy MH, Massignam A, Rossato L. 2007. Is crop N demand more closely related to dry matter accumulation or leaf area expansion during vegetative growth? Field Crops Research 100: 91-106. https://doi. org/10.1016/j.fcr.2006.05.009

Matthew C, Hernandez-Garay A, Hodgson J. 1996. Making sense of the link between tiller density and pasture production. Proceedings of the New Zealand Grassland Association 57: 83-87. https://doi. org/10.33584/jnzg.1995.57.2190
Ministry for the Environment. 2021. Action for healthy waterways. Retrieved 18 June https://environment. govt.nz/news/action-for-healthy-waterways/

Moot DJ, Griffiths W, Chapman D, Dodd M, Teixeira C. 2021. AgYields National Database - Past, present and future data collection and collation. Journal of New Zealand Grasslands 83: 15-24.

Myint TS, Wood LJ, Black AD. 2019. Optimisation of perennial ryegrass, white clover and plantain mixtures for maximum dry matter yield in an intensive pasture system. Presented at: 19th Australian Agronomy Conference. Wagga Wagga, New South Wales, Australia, 25-29 August. http:// www.agronomyaustraliaproceedings.org/

Nyfeler D, Huguenin-Elie O, Suter M, Frossard E, Connolly J, Lüscher A. 2009. Strong mixture effects among four species in fertilized agricultural grassland led to persistent and consistent transgressive overyielding. Journal of Applied Ecology 46: 683-691. https://doi.org/10.1111/j.13652664.2009.01653.x

Peoples MB, Brockwell J, Hunt JR, Swan AD, Watson L, Hayes RC, Li GD, Hackney B, Nuttall JG, Davies SL, Fillery IRP. 2012. Factors affecting the potential contributions of $\mathrm{N}_{2}$ fixation by legumes in Australian pasture systems. Crop \& Pasture Science 63: 759786. https://doi.org/10.1071/cp12123

Ryan-Salter TP, Black AD. 2012. Yield of Italian ryegrass mixed with red clover and balansa clover. Proceedings of the New Zealand Grassland Association 74: 201-208. https://doi.org/10.33584/ jnzg.2012.74.2862

Stewart A, Kerr G, Lissaman W, Rowarth J. 2014. Pasture and forage plants for New Zealand. 4th ed. Dunedin, New Zealand: New Zealand Grassland Association, 139 p. https://www.grassland.org.nz/ books.php

Vibart RE, Vogeler I, Dodd M, Koolaard J. 2016. Simple versus diverse temperate pastures: aspects of soilplant-animal interrelationships central to nitrogen leaching losses. Agronomy Journal 108: 2174-2188. https://doi.org/10.2134/agronj2016.04.0193 